\title{
Outcome and prognostic factors of pleural mesothelioma after surgical diagnosis and/or pleurodesis
}

\author{
Mariette Baud, MD, ${ }^{\mathrm{a}, \mathrm{b}}$ Salvatore Strano, MD, PhD,${ }^{\mathrm{c}}$ Agnes Dechartres, MD, ${ }^{\mathrm{d}}$ Rami Jouni, MD, \\ Frederic Triponez, MD, PhD, ${ }^{\mathrm{c}}$ Christos Chouaid, MD, PhD, ${ }^{\mathrm{b}}$ Patricia Forgez, PhD, ${ }^{\mathrm{a}}$ Diane Damotte, MD, PhD, ${ }^{\mathrm{e}}$ \\ Nicolas Roche, $\mathrm{MD}, \mathrm{PhD},{ }^{\mathrm{f}}$ Jean-François Régnard, $\mathrm{MD},{ }^{\mathrm{c}}$ and Marco Alifano, $\mathrm{MD}, \mathrm{PhD}^{\mathrm{a}, \mathrm{c}}$
}

Objective: The objective of this study was to evaluate long-term survival and prognostic factors in patients with malignant pleural mesothelioma.

\begin{abstract}
Methods: All consecutive patients referred for surgical diagnosis and/or pleurodesis for malignant pleural mesothelioma between 2000 and 2010 were studied. The following parameters were prospectively recorded: age, sex, tobacco consumption, asbestos exposure, type and duration of symptoms, American Society of Anesthesiologists (ASA) score, body mass index, preoperative C-reactive protein levels, white blood cells and platelet count, pachypleuritis on chest radiograph, type of diagnostic surgical procedure, histologic type, modality of pleurodesis, and chemotherapy. Survival was assessed on March 1, 2011.
\end{abstract}

Results: A total of 170 patients were included. For the entire population, median survival was 12 months (95\% confidence interval [CI], 10-15). Two-, 5-, and 7-year overall survival was 26\% (95\% CI, 19-35), $11 \%$ (95\% CI, 6-21), and 5\% (95\% CI, 9-22), respectively. Asbestos exposure, age, ASA class III versus ASA classes I and II, nonepithelioid histology, C-reactive protein levels $>3 \mathrm{mg} / \mathrm{L}$, and white cell count $>12,000 / \mathrm{mm}^{3}$ influenced outcome in univariate analysis. Multivariate analysis showed that nonepithelioid histology (hazard ratio [HR], 2.76; 95\% CI, 1.50-5.08); age (HR, 1.05; 95\% CI, 1.01-1.08); C-reactive protein levels between 4 and $50 \mathrm{mg} / \mathrm{L}$, and $>51$ (HR, 2.28; 95\% CI, 1.18-4.42; and HR, 2.69; CI, 1.29-5.60, respectively); and leukocytosis $>12,000 / \mathrm{mm}^{3}$ (HR, 2.28; 95\% CI, 1.22-4.25) were independent worse survival predictors.

Conclusions: Median survival in an unselected population of patients with malignant pleural mesothelioma treated nonsurgically is 12 months. Nonepithelioid histology, older age, abnormal C-reactive protein levels, and leukocytosis are independent predictors of worse survival. (J Thorac Cardiovasc Surg 2013;145:1305-11)

Malignant pleural mesothelioma (MPM) remains a public health issue, although asbestos use was discontinued approximately 2 decades ago in most countries, the incidence of the disease is currently stable. ${ }^{1-3}$ Furthermore, several working categories are still exposed to asbestos during maintenance or renovation work because of the lack of constant application of protection measures. ${ }^{4}$ Diagnosis is often late because symptoms are rather unspecific, particularly at early stages of the disease. ${ }^{5}$ Histology is mandatory

\footnotetext{
From INSERM Unit 938, ${ }^{\mathrm{a}}$ CdR Saint Antoine, Paris, France; the Department of Pneumology, ${ }^{\text {b }}$ Saint Antoine Hospital, AP-HP, Paris, France; the Department of Thoracic Surgery, ${ }^{c}$ Unit of Clinical Epidemiology, ${ }^{d}$ Hôtel-Dieu Hospital, AP-HP, Paris Descartes University, Paris, France; and Pathology e and Pneumology, ${ }^{\mathrm{f}}$ Hôtel-Dieu Hospital, AP-HP, Paris Descartes University, Paris, France.

Disclosures: Authors have nothing to disclose with regard to commercial support. M.B. and S.S. contributed equally to this work.

Presented in part at the Congress of French Society of Thoracic and Cardiovascular Surgery, Paris, France, December 9, 2011.

Received for publication April 15, 2012; revisions received Aug 12, 2012; accepted for publication Sept 13, 2012; available ahead of print Oct 15, 2012.

Address for reprints: Marco Alifano, MD, PhD, Department of Thoracic

Surgery, Hôtel-Dieu Hospital-Paris Descartes University, 1, Place du Parvis

Notre-Dame, 75181 Paris, France (E-mail: marco.alifano@htd.aphp.fr).

$0022-5223 / \$ 36.00$

Copyright (c) 2013 by The American Association for Thoracic Surgery

http://dx.doi.org/10.1016/j.jtcvs.2012.09.023
}

for the diagnosis but is often difficult, requiring large tissues samples to allow assessment of fat or intercostal muscle invasion by the mesothelial proliferation as well as immunohistochemical staining. ${ }^{6,7}$ Therefore, a surgical biopsy is frequently required. ${ }^{6,7}$

Despite chemotherapy progresses-particularly with the use of new antimetabolites pemetrexed ${ }^{8}$ and ralitrexed ${ }^{9}$ the impact on survival is moderate. Large-scale studies of a multimodality therapy based on association of chemotherapy and aggressive surgery (extrapleural pneumonectomy) showed disappointing results, with a 5-year survival of approximately $15 \% .^{10-12}$ Nevertheless, our knowledge on long-term outcome comes from few therapeutic studies and registries; therefore, prognostic factors are heterogeneous and often discordant among these different reports. ${ }^{13-16}$ This study aimed at assessing survival and its determinants in a series of unselected patients with MPM.

\section{METHODS}

Clinical and pathologic data of all patients referred to the thoracic surgery department of Hôtel-Dieu Hospital, Paris, France, between November 1, 2000, and October 31, 2010, for video-assisted or open pleural biopsy and/or pleurodesis for MPM were collected prospectively and reviewed retrospectively. Patients undergoing surgery in a curative intent by 


\section{Abbreviations and Acronyms \\ $\mathrm{CI}=$ confidence interval \\ $\mathrm{CRP}=\mathrm{C}$-reactive protein \\ $\mathrm{IL} \quad=$ interleukin \\ MPM $=$ malignant pleural mesothelioma}

extrapleural pneumonectomy were not included. Pleurectomy/decortication is not performed at our institution. For all patients, pathologic diagnosis was performed by board-certified pathologists highly specialized in thoracic pathology. All cases were also reviewed by the French national MPM panel (Mesopath Group).

The following parameters were recorded: age, sex, tobacco consumption, asbestos exposure, type and duration of symptoms (cough, dyspnea, pain, weight loss), American Society of Anesthesiologists score, body mass index, preoperative C-reactive protein (CRP) levels, white blood cells and platelet count, presence of pachypleuritis on chest radiograph, type of diagnostic surgical procedure (open vs video assisted), and histologic type. C-reactive protein levels were measured by nephelometry as part of the routine preoperative workup. The lower limit of detection was $3 \mathrm{mg} / \mathrm{L}$, which was chosen as the cutoff. Based on empirical clinical relevance, a second cutoff was set at $50 \mathrm{mg} / \mathrm{L}$.

Data on long-term outcome were obtained by direct phone interviews of patients, family (in case of deceased patients), and referring physicians. When no clinical follow-up was available (deceased patients, impossibility of contacting family, retired referring physicians), information on vital status per March 1,2011, was obtained through the municipality of birth of the patient.

Informed consent was obtained from patients or relatives (in the case of deceased patients). The research was conducted according to recommendations outlined in the Helsinki Declaration. Institutional review board approval was obtained.

\section{Patient Management}

All patients underwent thoracic and upper abdominal computed tomographic scan. Surgery was carried out under general anesthesia, using a 2-port technique in case of video-assisted thoracoscopy. Decision of performing talc pleurodesis was based on clinical and radiologic data, and on the perioperative aspect of the pleura and results of frozen sections analysis.

Our surgical institution is a tertiary referral center, with most patients addressed by several physicians and different hospitals. After discharge, patients were managed by referring physicians. Thus, indications for chemotherapy and timing with respect to interventions were largely variable. Chemotherapy proposition was discussed individually following multidisciplinary evidence-based meetings. Although no uniform protocol was applied, associations of platinum salts (gemcitabine) and of platinum salts (pemetrexed) were used primarily before and after 2005 , respectively.

\section{Data Analysis}

Data processing and analysis were performed with $\mathrm{R}$ version 2.15.1, a language and environment for statistical computing (R Foundation for Statistical Computing, Vienna, Austria). Results are expressed as percentage, mean \pm standard deviation for normally distributed, and median (first quartile, third quartile) for non-normally distributed, quantitative variables. Survival analysis was carried out using the Kaplan-Meier method, and univariate comparisons of curves were performed using log-rank tests. Crude hazard ratios were also estimated using univariate Cox models. All the variables associated significantly with survival in univariate analysis were entered into a multivariate Cox model to identify independent predictors of survival. A $P$ value $<.05$ was considered significant.

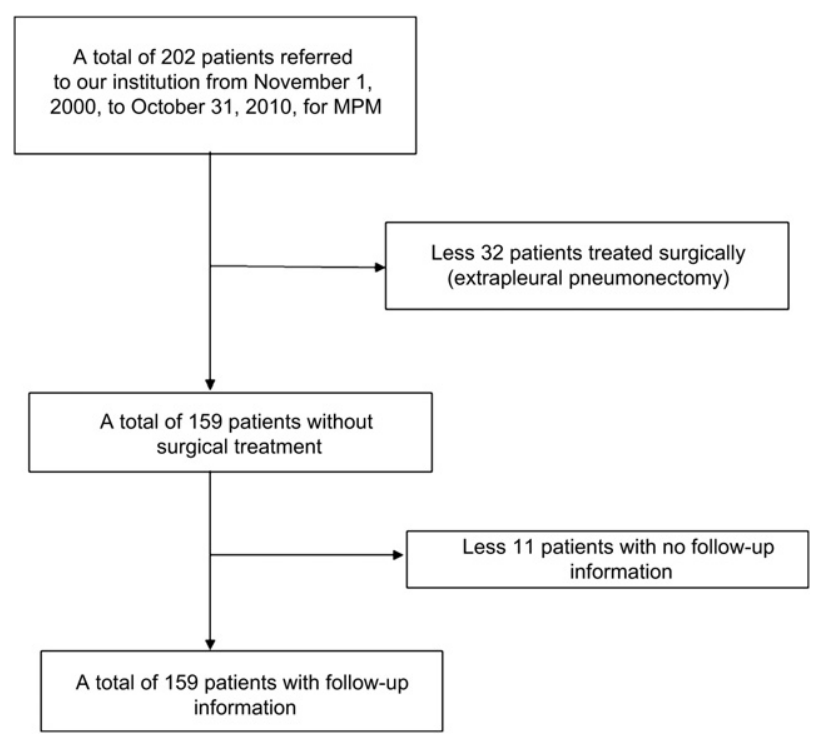

FIGURE 1. Flow diagram of patients. MPM, Malignant pleural mesothelioma.

\section{RESULTS}

\section{Patients Characteristics}

Of 202 surgical procedures in patients with MPM, 32 had a curative intent. The remaining 170 patients

TABLE 1. Patient characteristics

\begin{tabular}{|c|c|}
\hline Variable & n $(\%)$ or mean \pm SD \\
\hline \multicolumn{2}{|l|}{ Demographics and risk factors } \\
\hline Gender, men & $121(71)$ \\
\hline Age, years & $72.7 \pm 9.6$ \\
\hline Identified asbestos exposure & $73(46)$ \\
\hline History of previous malignancy & $25(15)$ \\
\hline Smokers or ex-smokers & $81(48)$ \\
\hline \multicolumn{2}{|l|}{ Initial presentation } \\
\hline Dyspnea, chest pain, cough & $125(75), 57(34), 34(20)$ \\
\hline Weight loss & $40(25)$ \\
\hline $\begin{array}{l}\text { Right-sided, left-sided, bilateral } \\
\text { localization }\end{array}$ & $105(64), 58(35), 2(1)$ \\
\hline \multicolumn{2}{|l|}{ Biology } \\
\hline CRP, median & $22.5(\mathrm{Q} 1,6 ; \mathrm{Q} 3,75)$ \\
\hline $\mathrm{CRP} \leq 3 \mathrm{mg} / \mathrm{L}$ & $28(18)$ \\
\hline $\mathrm{CRP}>3 \mathrm{mg} / \mathrm{L}$ & $130(82)$ \\
\hline $\mathrm{CRP}=3-50 \mathrm{mg} / \mathrm{L}$ & $79(50)$ \\
\hline $\mathrm{CRP}>50 \mathrm{mg} / \mathrm{L}$ & $51(32)$ \\
\hline Blood leukocytes count $/ \mathrm{mm}^{3}$ & $8907 \pm 2658$ \\
\hline Platelets count $/ \mathrm{mm}^{3}$ & $354,800 \pm 129,486$ \\
\hline \multicolumn{2}{|l|}{ Surgery } \\
\hline ASA I, II, III & $5(4), 92(65), 44(31)$ \\
\hline Video-assisted surgery & $157(92.3)$ \\
\hline Talc pleurodesis & $125(76)$ \\
\hline \multicolumn{2}{|l|}{ MPM } \\
\hline Epithelioid & $135(81)$ \\
\hline Biphasic, sarcomatoid, desmoplastic & $17(10), 9(5), 5(3)$ \\
\hline
\end{tabular}



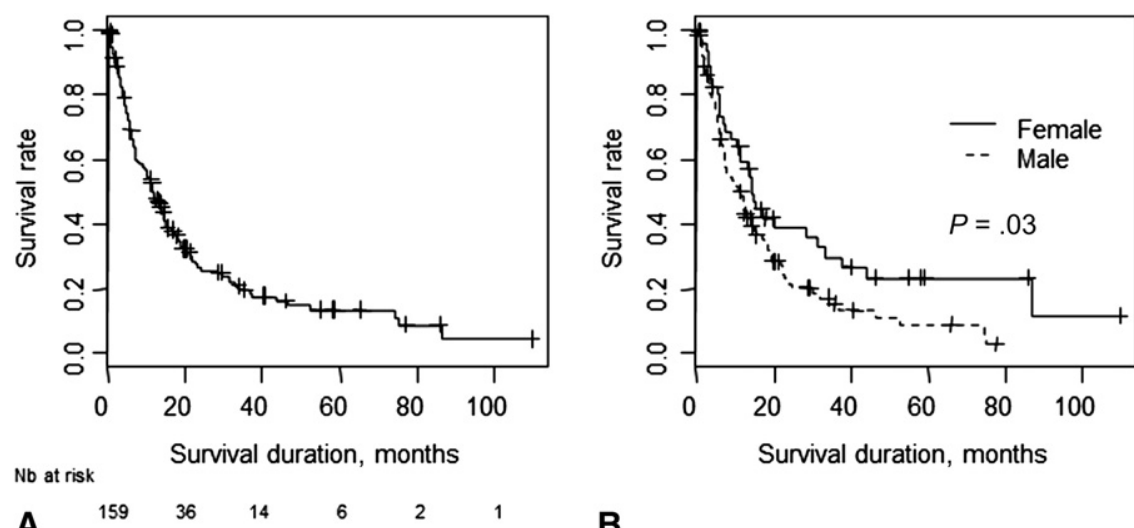

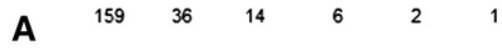

B
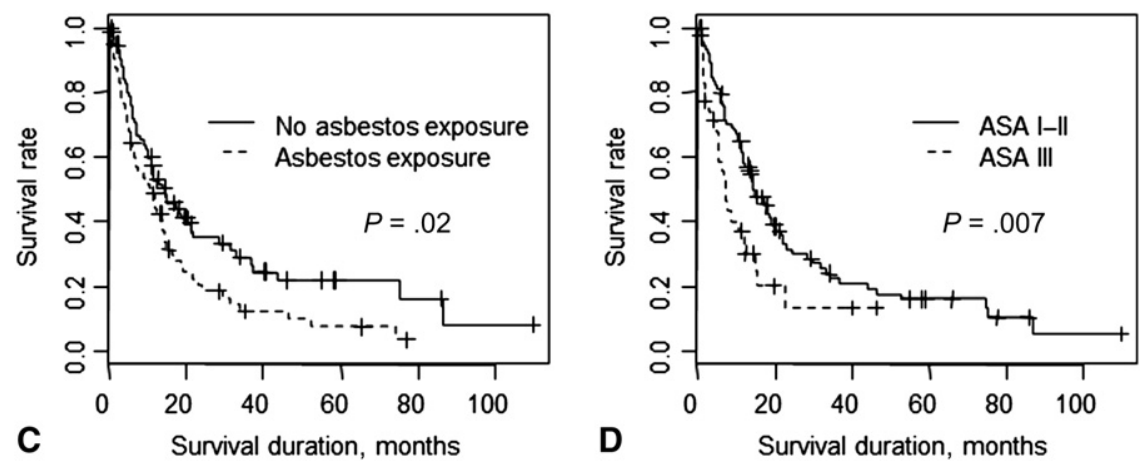

FIGURE 2. A, Kaplan-Meier overall survival of the whole population. B, Kaplan-Meier overall survival with respect to gender. C, Kaplan-Meier overall survival with respect to asbestos exposure. D, Kaplan-Meier overall survival with respect to American Society of Anesthesiologists (ASA) class.

underwent a diagnostic surgical procedure that was followed by a nonsurgical treatment, and were included in the study (Figure 1). Table 1 shows the main characteristics of patients, surgical procedures, and MPM type.

Thirteen patients $(7.7 \%)$ had a diagnostic minithoracotomy because of pachypleuritis without evident effusion. At thoracoscopy, only 10 patients $(5.9 \%)$ had a simple aspect of pleural inflammation, whereas for the remaining patients, nodules or pleural thickness were evident $(65.9 \%$ and $64.7 \%$ of patients, respectively) and often associated. Only 2 patients had a disease limited to the parietal pleura, whereas the remaining had parietal pleura involvement associated with visceral, mediastinal, or diaphragmatic pleural disease.

In a minority of patients, talc pleurodesis was not performed because of either pachypleuritis with no effusion $(\mathrm{n}=13,7.6 \%)$ or lack of sufficient intraoperative data (atypical presentation, thoracoscopic aspect, inconclusive histologic frozen sections) to justify talc pleurodesis. For these patients, instillation of povidone iodine was carried out. Postoperative mortality was $0.6 \%(n=1)$.

Postoperative treatment included chemotherapy associated with supportive care in 105 patients $(61.8 \%)$, and supportive care alone in the remaining patients.

\section{Long-Term Survival}

Information regarding survival was available for 159 patients $(94 \%)$ ). For 4 of 159 patients, information could be obtained only by interrogation of municipalities registries (because of deceased patients, families that couldn't be reached, and retired referring physicians). On completion of the study (March 2011), 40 of these patients were alive and 119 were dead. Median survival was 12 months $(95 \%$ confidence interval [CI], 10-15); a 2-, 5-, and 7-year overall survival was $26 \%$ (95\% CI, 19-35), $11 \%$ (95\% CI, 6-21), and $5 \%$ (95\% CI, 9-22), respectively (Figure 2). Characteristics of long term survivors $(\geq 5$ years) are detailed in Table 2.

\section{Predictors of Survival}

Table 3 shows the factors that were associated significantly with survival in univariate analysis. Age was associated with survival $(P=.008)$ and men had a worse prognosis $(P=.03$, Figure 2$)$. Weight loss was not associated significantly with survival, whereas asbestos exposure and American Society of Anesthesiologists class was $(P=.002$ and $P=.007$, respectively; Figure 2$)$. With respect to surgical and pathological data, non-epithelioid histology negatively affected outcome $(P=.005)$ (Figure 3$)$ 
TABLE 2. Characteristics of patients with survival $\geq 5$ years $(n=4)$

\begin{tabular}{lc}
\hline \multicolumn{1}{c}{ Variable } & n $(\%)$ or median $(\mathbf{Q 1}, \mathbf{Q 3})$ \\
\hline Demographics and risk factors & $2(50 \%)$ \\
Gender, men & $61(54,66)$ \\
Age, years & $2(50)$ \\
Identified asbestos exposure & $1(25)$ \\
History of previous malignancy & $1(25)$ \\
Smokers or ex-smokers & \\
Initial presentation & $3(75), 1(25), 0(0)$ \\
Dyspnea, chest pain, cough & $0(0)$ \\
Weight loss & $0(0), 2(50), 2(50)$ \\
Right-sided, left-sided, bilateral & \\
localization & $3(3,16)$ \\
Biology & $1(25)($ value 56$)$ \\
CRP & $7600(6575,9425)$ \\
CRP $>3$ mg/L & $(1>12,000$ value 12,500$)$ \\
Blood leukocytes count & $368,000(316,200,427,200)$ \\
Platelets count & $0(0), 4(100), 0(0)$ \\
Surgery & $3(75)$ \\
ASA I, II, III & \\
Talc pleurodesis & $4(100)$ \\
MPM & \\
Epithelioid &
\end{tabular}

whereas the presence of diffuse pachypleuritis did not $(P=.16)$. CRP levels $\leq 3 \mathrm{mg} / \mathrm{L}$, between 4 and 50 and $>51 \mathrm{mg} / \mathrm{L}$ were associated with survival $(P=.008$, Figure 3). Leukocytosis $\left(>12,000 / \mathrm{mm}^{3}\right)$ negatively affected outcome $(P=.03)$ (Figure 3$)$, whereas an increased platelet count $\left(>400,000 / \mathrm{mm}^{3}\right)$ did not influence survival $(P=.95)$.

Multivariate analysis showed that MPM histological type, age, CRP levels, and leukocytosis were independent predictors of worse survival (Table 4).

\section{DISCUSSION}

This large cohort study confirmed the poor survival of patients with MPM and identified independent prognostic factors including histologic type, age, and markers of systemic inflammation (ie, CRP levels and leukocyte count). The main limitations of our study are represented by the retrospective character of the study (precluding the exact assessment of cause of death and imposing the assessment of overall survival rather than disease-specific survival) and by the heterogeneity in postsurgical care, especially chemotherapy, preventing the possibility of rigorous survival analysis with respect to its administration. However, its main strengths are the large number of consecutive patients referred to a single surgical center who had exhaustive clinical and laboratory assessment as well as the long follow-up.

Knowledge of long-term outcome of patients with MPM is derived from a few registry studies, some retrospective observational studies, and a limited number of therapeutic
TABLE 3. Factors associated with survival in univariate analysis

\begin{tabular}{|c|c|c|}
\hline Variable & $\begin{array}{c}\text { Crude hazard } \\
\text { ratios }(95 \% \text { CI })\end{array}$ & $P$ value \\
\hline Age, years & $1.03(1.007-1.048)$ & .008 \\
\hline \multicolumn{3}{|l|}{ Gender } \\
\hline Men & $1.57(1.03-2.37)$ & .03 \\
\hline Women & 1 & \\
\hline \multicolumn{3}{|c|}{ Identified asbestos exposure } \\
\hline Yes & $1.54(1.05-2.24)$ & .02 \\
\hline No & 1 & \\
\hline \multicolumn{3}{|l|}{ ASA } \\
\hline III & $1.86(1.17-2.94)$ & .007 \\
\hline I-II & 1 & \\
\hline \multicolumn{3}{|l|}{ Histologic type } \\
\hline Nonepithelioid & $1.90(1.20-2.99)$ & .005 \\
\hline Epithelioid & 1 & \\
\hline \multicolumn{3}{|l|}{ CRP } \\
\hline$>3 \mathrm{mg} / \mathrm{L}$ & $1.97(1.16-3.36)$ & .01 \\
\hline$\leq 3 \mathrm{mg} / \mathrm{L}$ & 1 & \\
\hline \multicolumn{3}{|l|}{ CRP } \\
\hline$>50 \mathrm{mg} / \mathrm{L}$ & $2.47(1.37-4.46)$ & .003 \\
\hline $3-50 \mathrm{mg} / \mathrm{L}$ & $1.74(0.99-3.04)$ & .05 \\
\hline$\leq 3 \mathrm{mg} / \mathrm{L}$ & 1 & \\
\hline \multicolumn{3}{|l|}{ White cell count } \\
\hline$>12,000 / \mathrm{mm}^{3}$ & $1.75(1.05-2.92)$ & .03 \\
\hline$\leq 12,000 / \mathrm{mm}^{3}$ & 1 & \\
\hline
\end{tabular}

trials. $^{8-16}$ Studies of registries have been reviewed recently by Montanaro and colleagues ${ }^{16}$ : median survival times ranged from 5.0 to 13.2 months and 1-year survival rates from $29 \%$ to $46 \%$. Only 2 of 13 registry studies reported 5 -year survival rates, which were $5 \%$ in both cases. ${ }^{16}$

Therapeutic trials have reported variable results and, in all cases, included a very selected subset of patients. In a phase III study comparing the association of pemetrexed and cisplatin with cisplatin alone, 456 patients were evaluated. Median survival time in the pemetrexed-cisplatin arm was 12.1 months versus 9.3 months in the cisplatin arm, ${ }^{8}$ providing the basis of current recommendations for MPM chemotherapy. Although chemotherapy is often the sole treatment administered to patients with MPM, multimodality treatment, including radiation therapy, extensive surgery, and chemotherapy, is an option for selected patients with limited disease extension. However, following initial enthusiasm, ${ }^{17}$ more recent studies have shown that extrapleural pneumonectomy in the setting of a multimodality treatment is associated with a $25 \%$ to $42 \%$ 2-year survival rate. ${ }^{10-12,18}$ Two studies in 70 patients and 73 patients, showed 5-year survival rates of $15 \%$ and $10 \%$, respectively, raising the question of the real benefit of extensive surgery. ${ }^{11,12}$ Results of the randomized Mesothelioma and Radical Surgery trial do not seem to favor the association chemotherapy-extrapleural pneumonectomy 

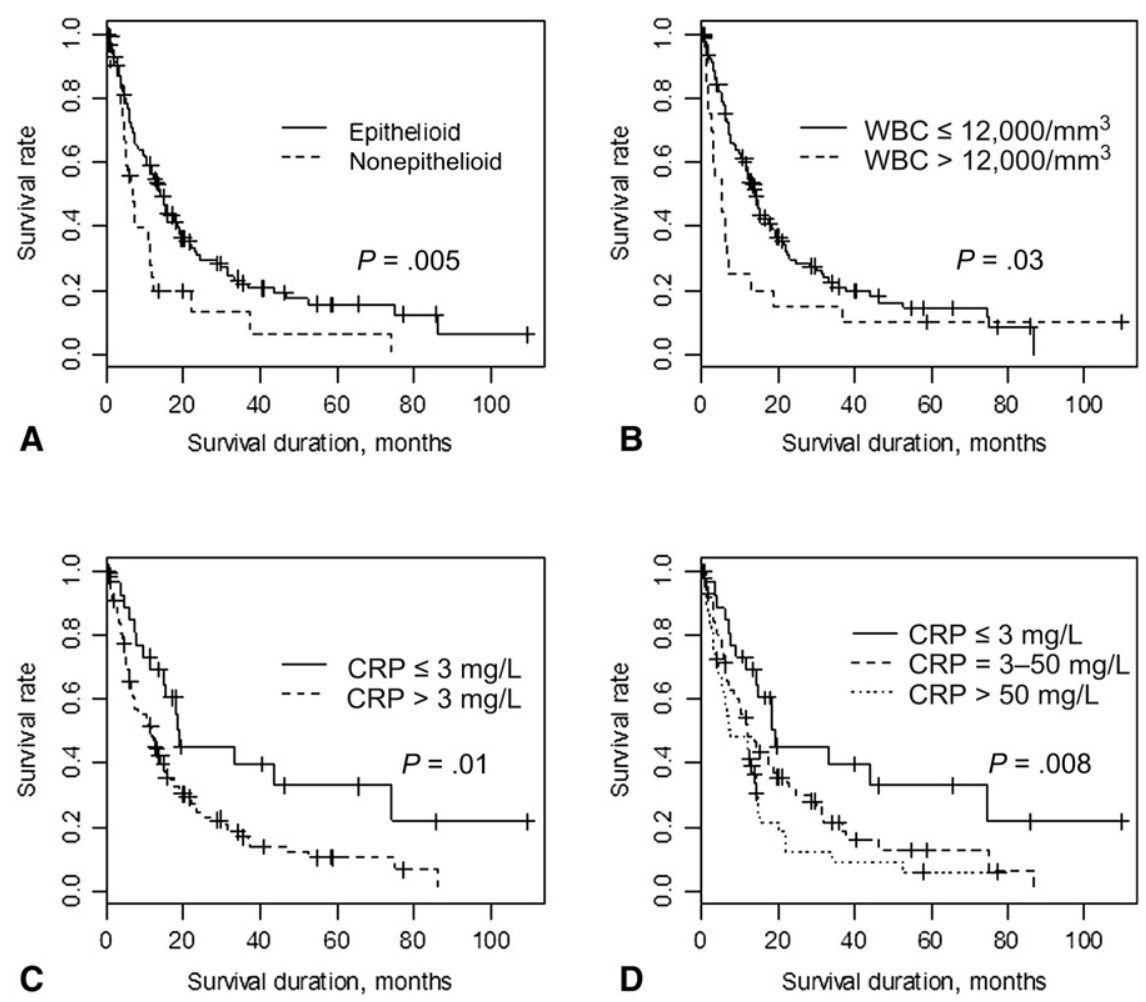

FIGURE 3. A, Kaplan-Meier overall survival with respect to histologic type. B, Kaplan-Meier overall survival with respect to blood leukocyte count. $\mathrm{C}$ and D, Kaplan-Meier overall survival with respect to C-reactive protein $(C R P)$ levels.WBC, White blood cells.

TABLE 4. Factors associated independently with survival in multivariate analysis

\begin{tabular}{lcc}
\hline \multicolumn{1}{c}{ Variable } & $\begin{array}{c}\text { Adjusted hazard } \\
\text { ratios }(\mathbf{9 5} \% \mathbf{C I})\end{array}$ & $\boldsymbol{P}$ value \\
\hline Nonepithelioid histologic type & $2.76(1.50-5.08)$ & .001 \\
Age, years & $1.05(1.01-1.08)$ & .006 \\
CRP & & \\
$\quad 3-50 \mathrm{mg} / \mathrm{L}$ & $2.28(1.18-4.42)$ & .01 \\
$\quad>50 \mathrm{mg} / \mathrm{L}$ & $2.69(1.29-5.60)$ & .008 \\
White cell count $>12,000 / \mathrm{mm}^{3}$ & $2.28(1.22-4.25)$ & .009 \\
\hline
\end{tabular}

$C I$, Confidence interval; $C R P$, C-reactive protein.

over chemotherapy-supportive care in MPM. ${ }^{19}$ It must be emphasized that these survival data have been obtained in patients participating in clinical trials (ie, sufficiently fit to undergo chemotherapy \pm extensive surgery), and thus are more likely to experience a longer survival than a nonselected population of MPM patients.

The outcome of unselected patients with MPM has been evaluated less extensively; therefore, prognostic factors are less known in these patients. In a Mayo Clinic report, ${ }^{12}$ all patients referred for MPM were analyzed. Three-year survival rates were $6 \%, 3.7 \%$, and $15 \%$ after biopsy, pleurectomy, or extrapleural pneumonectomy, respectively. ${ }^{12}$ Long-term survivors were observed only among patients treated by extrapleural pneumonectomy, with a 5-year survival rate of $15 \% .{ }^{12}$ However, this was a retrospective study and it is likely that long-term survivors were those individuals more fit and/or with less extensive disease.

In our study, we did not include patients treated by extrapleural pneumonectomy because of the substantial differences between these patients and the whole population of patients with MPM. Among our consecutive patients seen at the time of diagnosis, median survival was 12 months. Two-, 5-, and 7-year overall survival was $26 \%, 11 \%$, and $5 \%$, respectively, showing that long-term survival is not exceptional, even in these patients who were not treated with extensive surgery. Factors associated with long-term survival at univariate analysis were asbestos exposure, age, American Society of Anesthesiologists class, histology (nonepithelioid type), abnormal CRP levels, and increased white cell count.

With respect to CRP, abnormal values ( $>3 \mathrm{mg} / \mathrm{L}$ ), indicating some degree of systemic inflammation, were present in approximately $82 \%$ of our patients with MPM, whereas approximately one-third $(32 \%)$ had levels $>50 \mathrm{mg} / \mathrm{L}$. A leveldependent relationship with survival was observed, with an adjusted hazard ratio of 2.28 (95\% CI, 1.18-4.42) for CRP equal to $3-50 \mathrm{mg} / \mathrm{L}$ compared with $\mathrm{CRP}<3 \mathrm{mg} / \mathrm{L}$, and an adjusted hazard ratio of $2.69(95 \%$ CI, 1.29-5.60) for $\mathrm{CRP}>50 \mathrm{mg} / \mathrm{L}$ compared to $\mathrm{CRP}<3 \mathrm{mg} / \mathrm{L}$. Multivariate analysis showed that nonepithelioid histology, age, CRP levels, and leukocytosis were predictors of survival. Thus, 
systemic inflammation seems to be an independent predictor of poor outcome in nonsurgically treated patients with MPM. Proinflammatory cytokines and associated growth factors are involved in carcinogenesis through their effects on tumor cell growth, survival, proliferation, and migration. ${ }^{20}$ In addition, tumor cells themselves release proinflammatory cytokines. ${ }^{20}$ Serum CRP, a well-known and routinely measured marker of inflammation, is produced in the liver in response to high levels of proinflammatory cytokines, particularly interleukin (IL)-1, tumor necrosis factor- $\alpha$, and IL- $6 .{ }^{21}$ C-reactive protein has been identified as a prognostic factor in several tumors; with respect to intrathoracic malignancies, its relationship with prognosis has been suggested in advanced nonsmall cell lung cancer. ${ }^{22}$ Based on 2 different French cohorts, we have reported previously that CRP level is also an independent predictor of survival in resectable stage I to II nonsmall cell lung cancer. $^{23}$ Several mechanisms could explain the prognostic value of CRP. This protein could be a marker of IL-6 production by the tumor, thereby reflecting the tumor burden. ${ }^{21-23}$ Furthermore, CRP is known to block p53-induced apoptosis, ${ }^{24}$ and increased CRP levels could be an indirect marker of the tumor ability to maintain a protumor immune microenvironment. ${ }^{24}$

Comparison of our results with the available literature is difficult because only a few studies assessed the prognostic value of CRP in this setting. In particular, neither the European Organization for Research and Treatment of Cancer ${ }^{25}$ nor the Cancer and Leukemia Group B studies ${ }^{26}$ (based on 204 and 337 patients, respectively), assessed the prognostic role of CRP levels. Recently, Tanrikulu and colleagues ${ }^{27}$ reported that a CRP level $>50 \mathrm{mg} / \mathrm{L}$ was an independent predictor of survival in MPM patients; however, they did not investigate whether this relationship with survival was level dependent. Similarly, Kao and associates ${ }^{28}$ in a phase II study comparing thalidomide alone with thalidomide associated with cisplatin-gemcitabine in MPM found that increases in vascular endothelial growth factor and CRP at baseline were predictors of poor outcome in both treatment arms.

Identification of patients with poor prognosis could be useful for individual tailoring of treatment strategies. C-reactive protein measurement, together with other available clinicopathologic parameters, could help in identifying patients who require a more aggressive treatment or, on the contrary, could help in avoiding aggressive multidisciplinary management in severely ill patients that showing several negative prognostic factors. These remain to be demonstrated formally in adequately designed studies.

In conclusion, survival of patients with MPM remains poor. Chemotherapy and multimodal treatment strategies also involving curative surgery could improve survival in some patients. Knowledge of prognostic factors, including
CRP levels, could help in tailoring treatment options to each individual patient.

\section{References}

1. Marinaccio A, Binazzi A, Marzio DD, Scarselli A, Verardo M, Mirabelli D, et al. Pleural malignant mesothelioma epidemic: incidence, modalities of asbestos exposure and occupations involved from the Italian National Register. Int J Cancer. 2012;130:2146-54.

2. Craighead JE. Epidemiology of mesothelioma and historical background. Recent Results Cancer Res. 2011;189:13-25.

3. Price B, Ware A. Time trend of mesothelioma incidence in the United States and projection of future cases: an update based on SEER data for 1973 through 2005. Crit Rev Toxicol. 2009;39:576-88.

4. Olsen NJ, Franklin PJ, Reid A, de Klerk NH, Threlfall TJ, Shilkin K, et al. Increasing incidence of malignant mesothelioma after exposure to asbestos during home maintenance and renovation. Med J Austr. 2011;195:271-4.

5. Ducko CT, Sugarbaker DJ. Pleural tumors. In: Cooper JD, Deslauriers J, Lerut AEMR, et al, eds. Pearsons's thoracic \& esophageal surgery. 3rd edition. Philadelphia: Churchill Livingstone; 2008:1121-36.

6. Moran CA, Wick MR, Suster S. The role of immunohistochemistry in the diagnosis of malignant mesothelioma. Semin Diagn Pathol. 2000;17:178-83.

7. Husain AN, Colby TV, Ordóñez NG, Krausz T, Borczuk A, Cagle PT, et al. Guidelines for pathologic diagnosis of malignant mesothelioma: a consensus statement from the International Mesothelioma Interest Group. Arch Pathol Lab Med. 2009;133:1317-31

8. Vogelzang NJ, Rusthoven JJ, Symanowski J, Denham C, Kaukel E, Ruffie P, et al. Phase III study of pemetrexed in combination with cisplatin versus cisplatin alone in patients with malignant pleural mesothelioma. J Clin Oncol. 2003;21: 2636-44.

9. van Meerbeeck JP, Gaafar R, Manegold C, Van Klaveren RJ, Van Marck EA, Vincent M, et al. Randomized phase III study of cisplatin with or without ralitrexed in patients with malignant pleural mesothelioma: an intergroup study of the European Organisation for Research and Treatment of Cancer Lung Cancer Group and the National Cancer Institute of Canada. J Clin Oncol. 2005;23: 6881-9.

10. Tilleman TR, Richards WG, Zellos L, Johnson BE, Jaklitsch MT, Mueller J, et al. Extrapleural pneumonectomy followed by intracavitary intraoperative hyperthermic cisplatin with pharmacologic cytoprotection for treatment of malignant pleural mesothelioma: a phase II prospective study. J Thorac Cardiovasc Surg. 2009;138:405-11.

11. Yan TD, Boyer M, Tin MM, Wong D, Kennedy C, McLean J, et al. Extrapleural pneumonectomy for malignant pleural mesothelioma: outcomes of treatment and prognostic factors. J Thorac Cardiovasc Surg. 2009;138:619-24.

12. Schipper PH, Nichols FC, Thomse KM, Deschamps C, Cassivi SD, Allen MS, et al. Malignant pleural mesothelioma: surgical management in 285 patients. Ann Thorac Surg. 2008;85:257-64.

13. Flores RM, Krug LM, Rosenzweig KE, Venkatraman E, Vincent A, Heelan R, et al. Induction chemotherapy, extrapleural pneumonectomy, and postoperative high-dose radiotherapy for locally advanced malignant pleural mesothelioma: a phase II trial. J Thorac Oncol. 2006;1:289-95.

14. Rea F, Marulli G, Bortolotti L, Breda C, Favaretto AG, Loreggian L, et al. Induction chemotherapy, extrapleural pneumonectomy (EPP) and adjuvant hemithoracic radiation in malignant pleural mesothelioma (MPM): feasibility and results. Lung Cancer. 2007;57:89-95.

15. Hasani A, Alvarez JM, Wyatt JM, Bydder S, Millward M, Byrne M, et al. Outcome for patients with malignant pleural mesothelioma referred for trimodality therapy in western Australia. J Thorac Oncol. 2009;4:1010-6.

16. Montanaro F, Rosato R, Gangemi M, Roberti S, Ricceri F, Merler E, et al. Survival of pleural malignant mesothelioma in Italy: a population-based study. Int J Cancer. 2009;124:201-7.

17. Sugarbaker DJ, Flores RM, Jaklitsch MT, Richards WG, Strauss GM, Corson JM, et al. Resection margins, extrapleural nodal status, and cell type determine postoperative long-term survival in trimodality therapy of malignant pleural mesothelioma: results in 183 patients. J Thorac Cardiovasc Surg. 1999;117:54-63.

18. Van Schil PE, Baas P, Gaafar R, Maat AP, Van de Pol M, Hasan B, et al. Trimodality therapy for malignant pleural mesothelioma: results from an EORTC phase II multicentre trial. Eur Respir J. 2010;36:1362-9.

19. Treasure T, Lang-Lazdunski L, Waller D, Bliss JM, Tan C, Entwisle J, et al. Extra-pleural pneumonectomy versus no extra-pleural pneumonectomy for patients with malignant pleural mesothelioma: clinical outcomes of the 
Mesothelioma and Radical Surgery (MARS) randomised feasibility study. Lancet Oncol. 2011;12:763-72.

20. Lazennec G, Richmond A. Chemokines and chemokine receptors: new insights into cancer-related inflammation. Trends Mol Med. 2010;16:133-44.

21. Pepys MB, Hirschfield GM. C-reactive protein: a critical update. J Clin Invest. 2003;111:1805-12.

22. Koch A, Fohlin H, Sorenson S. Prognostic significance of C-reactive protein and smoking in patients with advanced non-small cell lung cancer treated with first-line palliative chemotherapy. J Thorac Oncol. 2009;4:326-32.

23. Alifano M, Falcoz PE, Seegers V, Roche N, Schussler O, Younes M, et al. Preresection serum $\mathrm{C}$-reactive protein measurement and survival among patients with resectable non-small cell lung cancer. J Thorac Cardiovasc Surg. 2011;142:1161-7.

24. Hara M, Matsuzaki Y, Shimuzu T, Tomita M, Ayabe T, Enomoto Y, et al. Preoperative serum C-reactive protein level in non-small cell lung cancer. Anticancer Res. 2007;27:3001-4.
25. Curran D, Sahmoud T, Therasse P, Van MJ, Postmus PE, Giaccone G. Prognostic factors in patients with pleural mesothelioma: the European Organization for Research and Treatment of Cancer experience. J Clin Oncol. 1998;16: 145-52.

26. Herndon JE, Green MR, Chahinian AP, Corson JM, Suzuki Y, Vogelzang NJ. Factors predictive of survival among 337 patients with mesothelioma treated between 1984 and 1994 by the Cancer and Leukemia Group B. Chest. 1998;113: 723-31.

27. Tanrikulu AC, Abakay A, Kaplan MA, Kucukoner M, Palanci Y, Evliyaoglu O et al. A clinical, radiographic and laboratory evaluation of prognostic factors in 363 patients with malignant pleural mesothelioma. Respiration. 2010;80:480-7.

28. Kao SC, Harvie R, Paturi F, Taylor R, Davey R, Abraham R, et al. The predictive role of serum VEGF in an advanced malignant mesothelioma patient cohort treated with thalidomide alone or combined with cisplatin/gemcitabine. Lung Cancer. 2012;75:248-54. 